\title{
Principles of preserving the architectural heritage on the example of architectural and planning structure restoration in Rostov-on-Don after the Great Patriotic War
}

\author{
Irina Moskalenko ${ }^{1}$, Svetlana Sheina ${ }^{2}$, and Karina Chubarova $^{2 *}$ \\ ${ }^{1}$ South Federal University, 344006, Rostov-on-Don, Russia \\ ${ }^{2}$ Don State Technical University, 344010, Rostov-on-Don, Russia
}

\begin{abstract}
This work is devoted to the transformation of the architectural and planning structure of the Rostov-on-Don city in the first half of the twentieth century. Its main shortcomings, identified in the 1920s - 1930s, and the ways of solving them are analyzed. The attempts to create a new socialist city are considered. It covers the destruction caused by the German fascist invaders during the two occupations of Rostov-on-Don, which accounted for more than one third of its buildings. The main stages and principles of city planning structure restoration are presented. The projects of restoration and reconstruction, their implementation and detailed planning of Rostov-on-Don are considered.
\end{abstract}

\section{Relevance}

Currently, the problem of preserving the existing architectural heritage and its interaction with the objects of new construction, their perception both at the level of mass and professional consciousness is acute, which involves not only their preservation, but also transformation. In this regard, an attempt to determine the features of the architectural and urban planning system continuity and evolution in the periods of the urban culture formation and the post-war restoration of Rostov is relevant.

The problem of restoring the architectural appearance of the city after the Great Patriotic War has not been sufficiently studied and requires a more complete study, despite a significant number of historical and regional studies and works on the history of architecture of Rostov-on-Don.

Scientific novelty lies in the fact that:

the revealed factual material on the Rostov-on-Don architecture restoration (associated with the legacy of Academician V.N. Semenov) has been introduced into scientific use for the first time;

the stages of Rostov-on-Don restoration after the Great Patriotic War have been revealed;

ten principles of post-war reconstruction of fifteen largest cities have been identified.

\footnotetext{
${ }^{*}$ Corresponding author: karina.chubarova@yandex.ru
} 


\section{Disadvantages of the planning structure in the pre-war period and attempts to improve the situation}

By the beginning of the Great Patriotic War, Rostov-on-Don became a part of the largest cities of the Soviet Union. Its architectural and planning solution required serious changes, since during this period one of the main tasks assigned to the architects was the reconstruction of the formed spatial structure of the city. The architectural and urban planning practice of the 19th century became the cause of a number of shortcomings, the need to eliminate which arose in the pre-war period (Fig. 1).

Disadvantages of the planning structure of Rostov-on-Don in the pre-war period

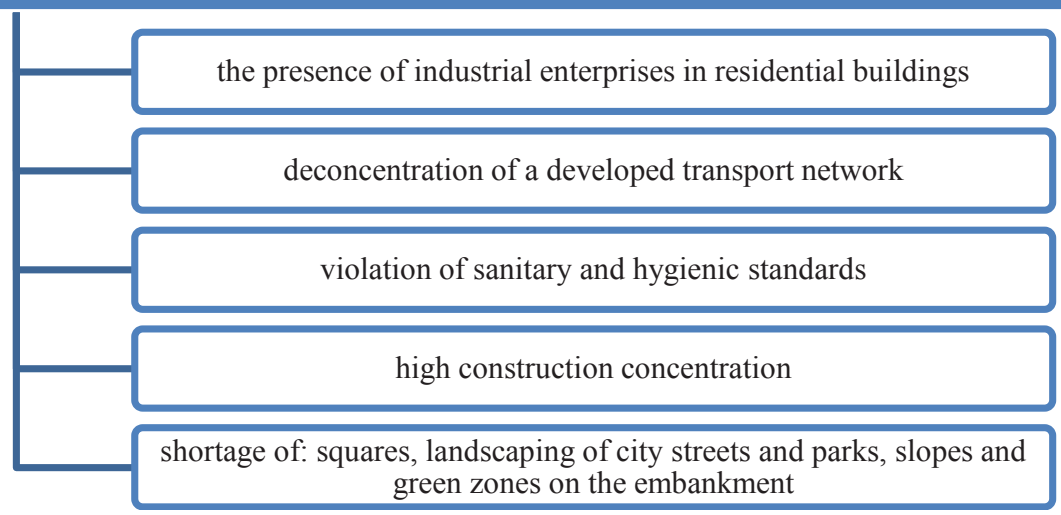

Fig. 1. Disadvantages of the planning structure of Rostov-on-Don in the pre-war period

The main directions and regulations of architecture, urban planning and construction activities were determined by the directives and decrees of 1926-1935. In accordance with them, a number of general plans for the city development were issued, including the draft of the general plan of the Rostov-on-Don city by the architect V. N. Semenov and the architect-artist V. V. Semenov-Prozorovsky of 1936-1938. In this work, the architects solved the problems corresponding to the main trends of that period:

to turn the city "to face the river";

to preserve and improve the existing central composition (Bolshaya Sadovaya street and the squares connected with the embankment);

to create a number of secondary centers;

to optimize the public transport system (for example, move the tram line from the main street to the secondary streets and connect the tram with the train station);

to register the entrance to the city from the railway side;

to create new traffic junctions at different levels;

to add green spaces on the outskirts and in the city center.

In addition, "... the city lacked expressiveness, individuality ... It was desirable, applying all the achievements of the socialist realism method and using the critically mastered southern Russian classics, to express the interests and ideology of Soviet, socialist society by the language of architecture" [1].

The project was not implemented (it was not considered and approved by the Council of People's Commissars). The main decisions of this plan formed the basis of the project for the post-war restoration and reconstruction of the Rostov-on-Don city in 1945 (architect V. N. Semenov). Thus, the attempts to solve the problem of improving the architectural and 
planning structure, to give it the appearance of a new socialist city, were undertaken in the pre-war period, but were not implemented.

\subsection{Destruction caused by military operations}

During the Great Patriotic War, Rostov was occupied by the Nazi invaders twice: from October to November 1941 and from July 1942 to February 1943. The territory of the historical center of the city (mainly the Leninsky district), quarters, squares and central thoroughfares of the city were most destroyed: "... especially in the area of Engels Street, Budennovsky Avenue and other thoroughfares of the center" [2]. The Zheleznodorozhny and Proletarsky districts (the territory of the former Nakhichevan) suffered to a lesser extent. "... more than 1/3 of all residential and public buildings" [3] were destroyed in the city (Fig.2).

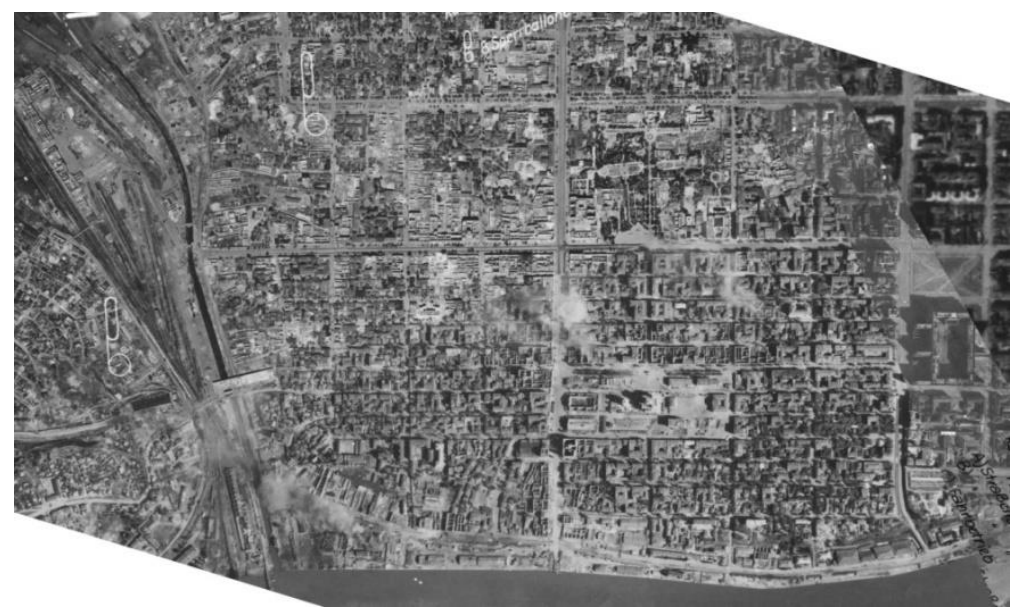

Fig. 2. Aerial photography of the central part of Rostov-on-Don 1943.

Industrial facilities also received significant damage: "... 238 industrial enterprises, including Selmash, were blown up, burned, destroyed and damaged" [4].

The transport infrastructure of the city has also suffered greatly. The river port was damaged, the railway station, repair shops, railway tracks, engineering networks, urban transport were completely destroyed, and urban landscaping was also damaged: “... trolleybus, tram and bus fleets, water supply, sewerage, ... trade network and public catering network were destroyed ... 26 gardens and parks of the city were destroyed and damaged. Over 4 million trees were cut down" [4].

Thus, about one third of the city's territory was destroyed, in the course of its work "... the extraordinary State Commission determined the amount of material damage caused to the city in the amount of three hundred million rubles" [5].

\subsection{Stages of Rostov-on-Don restoration}

Rostov-on-Don was restored in two stages: the first - from February 14, 1943 to 1945 and the second - from 1946 to 1956 . The stages differ in the requirements and conditions of the restoration work. At the first stage, before the end of hostilities, industrial enterprises and the railway economy, the least damaged "boxes" of buildings, were restored in their places, and new residential buildings were built on the outskirts of the city. All this influenced the implementation of the general plan of Rostov-on-Don, approved in 1945. 
The second stage began with the adoption by the USSR government of the five-year Stalinist plan for 1946-1950. At this stage, the implementation of the artistic concept of restoration is carried out, the solution of tasks for the new socialist city creation, which would reflect the Triumph of Victory in the Great Patriotic War. The implementation of the concept was entrusted to the chief architect of the city.

At this stage, standardization and development of uniform building codes for the entire country was carried out. The rationalization movement was in development process, SRTS were created, new achievements and technologies, rationalization methods of work were introduced into construction. For mass construction, the standard sizes of building elements were reduced, a series of standard parts and structures were developed and introduced, building materials were used rationally and economically. Plants for the building materials production were being built.

Thus, the post-war restoration of Rostov-on-Don was carried out in two stages. By 1957, the bulk of industrial enterprises, passenger and rail transport, bridges, city networks, main administrative buildings, and housing stock were restored. Despite the restoration of old buildings and the construction of new buildings (the amount of living space increased to 3,070 thousand $\mathrm{m}^{2}$ against the pre-war 2,616 thousand $\mathrm{m}^{2}$ ) [6], the housing problem was not solved, since population growth exceeded the increase in living space, and construction plans over the years of restoration were not fully implemented. In 1957, a new stage of construction started - standard construction.

\section{The concept of restoration of 15 cities of the RSFSR}

Restoration projects started to be developed after the return from evacuation to Moscow of the Academy of Architecture and Education of the Committee for Architecture Affairs in 1943. In 1944-1945, the projects for the restoration and reconstruction of cities began to be developed by young architects under the guidance of the most prominent architects of the country.

In 1945, the Council of People's Commissars of the USSR adopted a resolution on urgent measures to restore 15 cities of the RSFSR liberated from the Nazi occupation: Bryansk, Velikiye Luki, Veliky Novgorod, Voronezh, Vyazma, Kalinin, Krasnodar, Kursk, Murmansk, Novorossiysk, Orel, Pskov, Rostov-on-Don, Sevastopol, Smolensk. Recovery projects were coordinated by the clear leadership directives. In 1945, on the basis of the state directives, the chairman of the Committee for Architecture Affairs A.G. Mordvinov set out a number of requirements for the projects of the cities' post-war restoration (Fig. 3) [7].

These requirements were corrected by the authors of the restoration projects, depending on the architectural and urban planning situation. Their analysis, considered in the works of T.G. Malinina and Yu.L. Kosenkova, makes it possible to formulate ten basic principles of the post-war reconstruction of 15 cities:

1. preservation and renewal of the existing spatial structure of the city;

2. preservation of the architectural and artistic individuality of the city and the formation of its architectural and artistic image;

3. creation of a system of spatial dominants:

a. spatial dominants - monuments and memorial complexes dedicated to the Great Patriotic War;

b. spatial dominants - objects of historical and cultural heritage;

c. large public buildings as spatial dominants of the restored city;

4. identification and accentuation of the architectural and urban planning complex of the city center; 
5. "Gates of the city" - the railway station as the most important architectural accent of the restored city;

6. landscaping and beautification of the city;

7. turn of the city "facing the river";

8. city zoning and new industrial and residential areas;

9. restoration and reconstruction of transport infrastructure;

10. regulation of number of storeys and building materials in the central part of the cities.

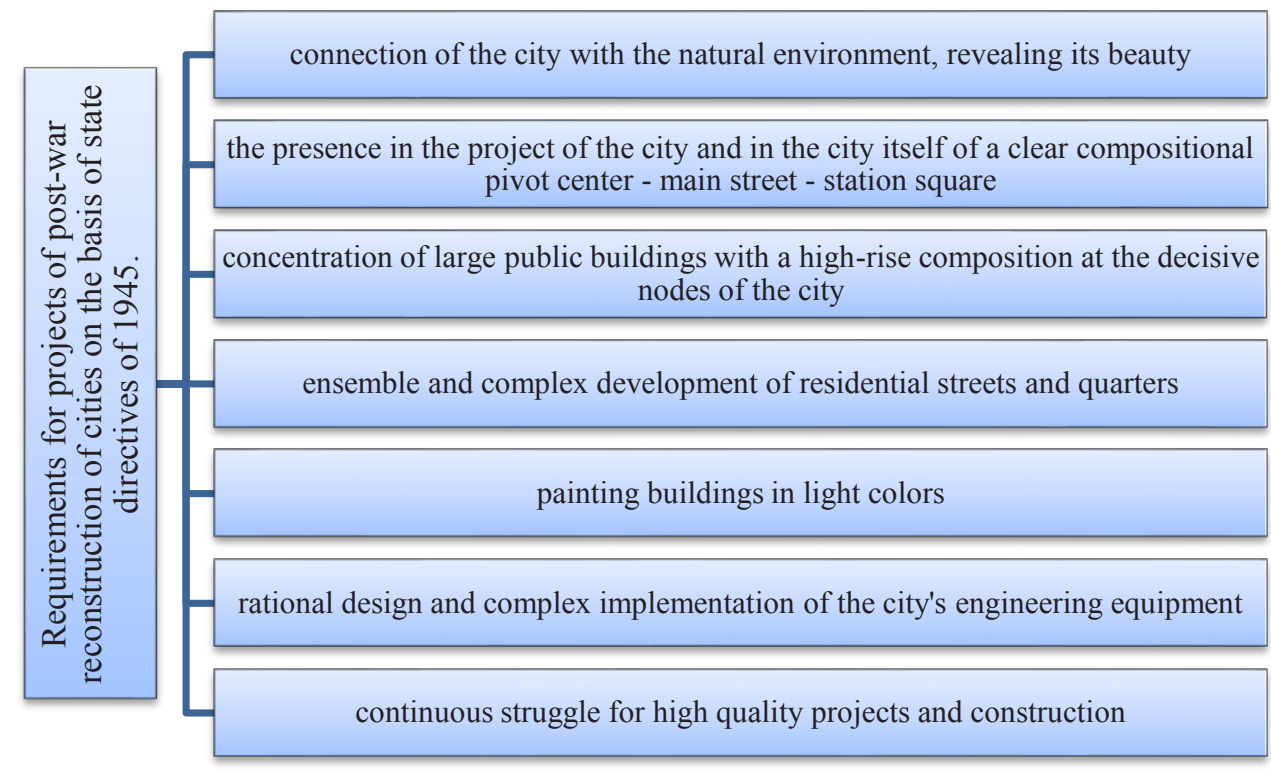

Fig. 3. Requirements for projects of the cities post-war reconstruction based on the state directives of 1945

In the project for Rostov-on-Don restoration, V.N. Semenov implemented ten principles, except for one point: spatial dominants - objects of historical and cultural heritage, since there were no objects related to cultural monuments in the urban development of Rostov-on-Don.

Thus, in 1945, the concept of the city as a whole appears, the structure of which is formed as a metaphor for Victory and Triumph over the Nazi troops - to restore the city, correct the flaws in the planning structure at a minimum cost and create the image of a new socialist city. In accordance with this concept, the General Plan of Rostov-on-Don was developed, approved by the Council of Ministers of the RSFSR by the Resolution No. 485 of August 9, 1945.

\section{Projects of V.N. Semenov and the detailed planning of Rostov- on-Don}

The basis of the general plan for the restoration and reconstruction of the city of Rostov-onDon (1945) was developed under the leadership of Academician V.N. Semenov (architects: I.G. Gainutdinov, V.S. Kolbin, V.V. Semenov-Prozorovsky, M. I. Tarakanov; engineers: N. I. Dubrovsky, M. M. Porfiriev, A. M. Yanshin; economists: A. G. Kazanskaya, Ya. P. Levchenko) [1], the ideas of the pre-war draft of the general plan of the city $1936-1938$ 
(V.N.Semenova and V.V.Semenov - Prozorovsky) were extended by a number of additional solutions (Fig. 4).

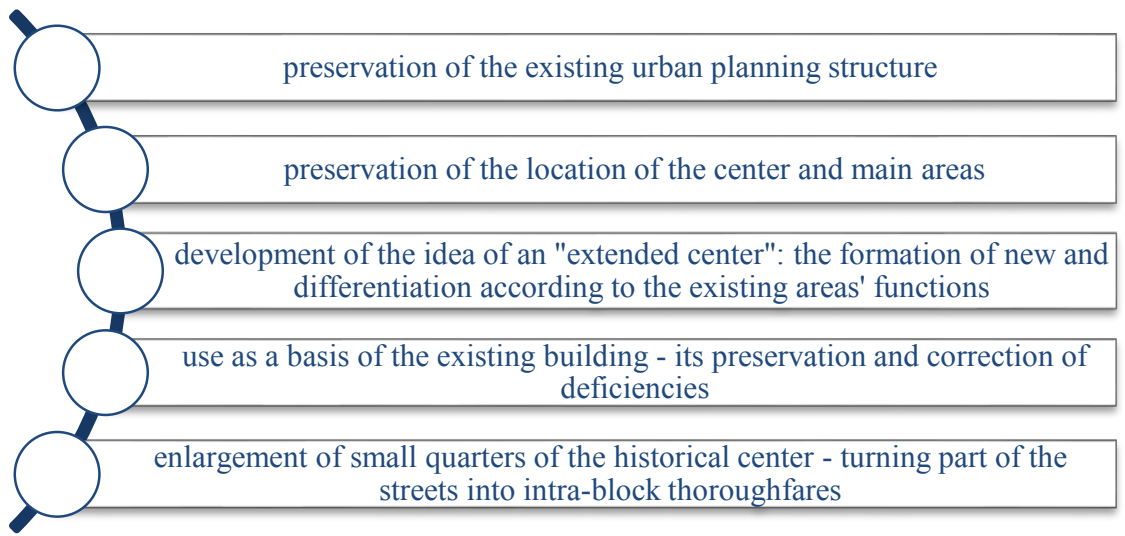

Fig. 4. Additional solutions for the master plan for the restoration and reconstruction of Rostov-onDon (1945)

Thus, on the basis of the existing urban planning system, the ideas of pre-war improvement of the planning and taking into account the destruction caused by the Great Patriotic War, a project for the restoration and reconstruction of Rostov-on-Don in 1945 was created. At the same time, V.N. Semenov used the principles of restoring fifteen Soviet cities. Its project was finalized in the projects of detailed planning by local architects under the guidance of the chief city architect Ya. A. Rebain and, in many respects, was implemented.

Detailed planning projects were developed in 1948-1949 in the architectural and design workshop under the Office of the Chief Architect of the Rostov-on-Don city under the leadership of L. L. Eberg. In the projects of the city central part (architects V.V. Leontyev, Kh. Kh. Chalkhushyan), the central part of the Zheleznodorozhny district, the NorthWestern section of the Oktyabrsky district (architect I.V. Baglai), the central part of the Leninsky district (architect I. V. Baglai) reflected the implementation of the principles, project proposals and ideas of V. N. Semenov on the formation of new secondary urban centers. In the projects of the detailed planning, the architects tried to make improvements and connect the general plan with the existing situation, to expand the proposals of V.N. Semenov. For example, to enlarge the city blocks not only in the center, but also on the periphery, to carry out landscaping, to reconstruct the transport infrastructure (Fig. 5, 6).

\begin{tabular}{|l|c|c|}
\hline Symbols & 1917 state & 1941 state \\
\hline$\square$ & Rostov-on-Don center & \\
- old city center & & \\
- center of Nakhichevan-on-Don \\
- complex of the united Rostov \\
and Nakhichevan-on-Don center \\
extended center complex \\
(project proposals and \\
implementation)
\end{tabular}






Fig. 5. Phased transformation of the urban landscaping structure and improvement in accordance with the post-war period projects

\begin{tabular}{|c|c|c|}
\hline Symbols & 1917 state & 1941 state \\
\hline $\begin{array}{l}\text { - landscaping from } 1749 \text { to } 1917 \\
\text { - landscaping from } 1917 \text { to } 1941 \\
\text { - landscaping in accordance with } \\
\text { the project proposals } \\
\text { - prospective landscaping }\end{array}$ & 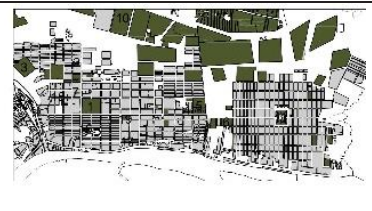 & 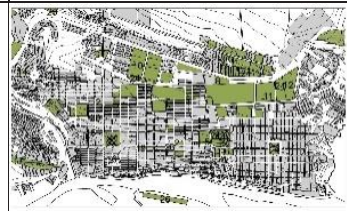 \\
\hline $\begin{array}{l}1945 \text { restoration and reconstruction } \\
\text { project }\end{array}$ & $\begin{array}{l}\text { Detailed planning project } \\
1948,1949\end{array}$ & Implementation \\
\hline 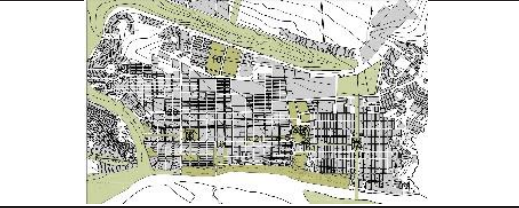 & 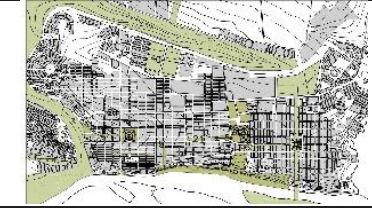 & 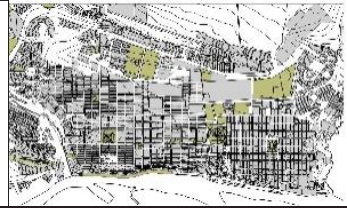 \\
\hline
\end{tabular}

Fig. 6. Revealing and emphasizing the architectural and urban planning complex of the city center

Not all conceptual proposals of V.N. Semenov and the projects of detailed planning, carried out under the leadership of L.L. Eberg, were implemented. The reasons for this are as follows:

- lack of funding;

- $\quad$ preservation of some of the restored industrial enterprises in their places;

- decisions of local authorities on incomplete dismantling and partial preservation of railway tracks on the embankment.

At the same time, the implementation of the Rostov central part project is primarily due to the comments and remarks made by the state institutions, in particular the Executive Committee of the Rostov-on-Don City Council, in the process of approving the project.

Thus, the monuments dedicated to the Great Patriotic War were not realized (they did not have a significant impact on urban development); the Kirov square has not been formalized; a new Railway Station Square with the transfer of the station building to it has not been created. The ensemble of the extended center is closed in the west by the existing Railway Station Square. There is no staircase from Pushkinskaya street to connect the center with the station; the descent to the embankment along the Podbelsky lane has not been completed, the industry has not been moved to a new industrial zone. Therefore, the development remained mixed in the center and other areas.

The proposals of V.N. Semenov for the enlargement of quarters in the center have been fragmentarily implemented: several buildings have been built in the streets: Temernitskaya street crossing Bratskiy lane (residential building in Bratskiy lane, 20-22, 1958) and Shaumyan street crossing Budennovskiy avenue (Central Department Store, Budennovskiy avenue, 28), Dolomanovskiy lane crossing Bolshaya Sadovaya street (residential building on Bolshaya Sadovaya street, 8, 1958). The old dominants were restored, and the MachineBuilding Institute was built from the new ones (now DSTU, Gagarin Square, 1, architects Ya. A. Rebain, P.S. Kalashnikov, Kh. Kh. Chalkhushyan, 1945). The implemented projects created the semantic framework of the urban structure, which differs from both the pre-war and the design options. The project of an extended center was implemented, in which the 
"gates to the center", the square of the House of Soviets and Maxim Gorky were designed, and a "procession road" was created. Secondary city centers were organized: the square named after V.I. Lenin (located in the north of the center), the square named after Y. Gagarin, the square named after Druzhinniki. Green spaces in the center and in other areas of the city have been restored and expanded: interior greening of the neighborhoods, courdoners has been created, a boulevard between Stanislavsky and Moskovskaya streets has been partially organized, old ones have been restored (named after M. Gorky, named after V. Mayakovsky) and the new ones have been projected (on the site of the old Novoposelenkovskoye cemeteries) parks. The system of utilities was restored and expanded, old and new buildings were connected to it. The streets were paved with asphalt (improved pavement), including filling from local materials. The turn of the city "facing the river" has not been fully completed: only the first stage of the embankment has been completed, its landscaping and greening have been created, stairs have been built - descents to the embankment at the end of Voroshilovsky and Budenovsky avenues, Gazetniy lane. The transport situation was optimized with the construction and restoration of overpasses and bridges across the Don River, the creation of new interchanges and tramways (moving them from the main street to the secondary ones), changing the profiles of streets not only in the center, but also to the outskirts. Finishing of the facades of new and renovated buildings was carried out in accordance with the recommendations of V.N. Semyonov. A point increase in the number of storeys in the center and on the periphery has been carried out. The individuality of the city is respected, despite the implementation of the general principles of city restoration.

Thus, despite the incomplete implementation, the main project proposals were implemented. An ensemble of an extended center, a "procession road", reflecting the Triumph of Victory over the German fascist invaders, has been created. The city has been turned "facing the river", a new panorama has been created from the river.

\section{Conclusion}

The need to eliminate shortcomings in the architectural and planning structure of the city appeared in the pre-war period, but was not realized. Its main ideas were included in the post-war city reconstruction project in 1945.

In connection with the destruction caused by military operations, the architects had an opportunity to implement the tasks and requirements set before them by the party and the government, with the lowest financial costs.

As a result of the restoration work carried out, the architectural and artistic appearance of the city was transformed, the principles and decisions of V. N. Semenov and the projects of detailed planning were embodied: the connection of the center with the embankment and other areas, the facades of the buildings were decorated in the prevailing style. All these decisions reflected the Triumph of Victory over the German fascist invaders. Despite the incomplete implementation of project proposals, a new socialist city was created.

\section{References}

1. V. N. Semenov, About the general plan of the city of Rostov-on-Don. Problems of Soviet urban planning (Moscow, Publishing House of the Academy of Architecture of the USSR, 1949).

2. State Archives of the Rostov Region № 4329, 1, unit 146. Information about the new town planning provisions of the planning and development of Rostov-on-Don, $12 \mathrm{p}$. (1957) 
3. State Archives of the Rostov Region P-4329, 1, unit 45 A brief overview of the restoration of Rostov-on-Don, 2 p. (1949)

4. State Archives of the Rostov Region P-4329, 1, unit 24 "Information about the future of Rostov-on-Don. Future Rostov ". 4 p.

5. Ya.A. Rebayn, Rostov strides into the future (Rostov Book Publishing House, Rostovon-Don, 1968)

6. State Archives of the Rostov Region P4329, 1, unit 145. Certificate of construction in Rostov-on-Don by the 40th anniversary of October. 7 p. (1957)

7. Yu.L. Kosenkova, Soviet city of the 1940s - first half of the 1950s. From creative pursuits to building practice (dissertation... Doctor of architecture: 18.00.01 - Theory and history of architecture, restoration and reconstruction of historical and architectural heritage, Moscow, 2000).

8. S G Sheina et al, IOP Conf. Ser.: Mater. Sci. Eng. 913, 042025 (2020)

9. V.S. Vagin, S.G. Sheina, K.V. Chubarova, Online Journal of Science 7(3) (28), 92 (2015)

10. S.G. Sheina, L.L. Babneko, P.A. Shumeev, Science of Science (electronic scientific journal) 5, (2013).

11. S.G. Sheina, L.L. Nikulshina, P.A. Shumeev, S.Yu. Gonezhuk, New technologies 3, $137-141(2012)$

12. I Yu Zilberova et al, IOP Conf. Ser.: Mater. Sci. Eng. 1083, 012058 (2021). 